\title{
"What kept me going was stubbornness": Perspectives from Swedish early career women academics in geography
}

\author{
Martina Angela CARETTA \\ West Virginia University \\ martinaangelacaretta@gmail.com \\ Natasha Alexandra WEBSTER \\ Stockholm University \\ natasha.webster@humangeo.su.se
}

Recibido: Junio 2016

Aceptado: Diciembre 2016

\begin{abstract}
The rise of neoliberalism is creating inequalities for women as they balance their private lives and career trajectories. Geography as a middle sized discipline bridging the social and physical sciences offers insights into the ways neoliberal policies are felt by early career women (ECW). Using a life course model, this study presents the results of a workshop which sought to explore the ways in which women geographers, in Sweden, perceive and experience obstacles in their career advancement and which coping strategies they put in place to overcome those. The results show the blurring of the ECW's work and private lives. We find the experiences of ECW in Swedish geography departments are consistent with those of women in other countries. We conclude that ECW carry extra burdens in their career trajectories as academics due to increasingly neoliberal working environments, lack of mentorship, and an increasing pressure to produce measurable outputs and precarious employment. We argue that initiatives and programs aimed at retaining women in academia need to take on a broader perspective acknowledging the entanglement of women's private and public spheres.
\end{abstract}

Keywords: Geography, early career women, academia, neoliberalism, Sweden.

"Lo que me hizo continuar fue la cabezonería": Perspectivas de las mujeres suecas al inicio de su carrera académica en Geografía

\section{RESUMEN}

El surgimiento del neoliberalismo está creando desigualdades para las mujeres para equilibrar sus vidas privadas y sus trayectorias profesionales. La geografía como una disciplina de tamaño 
mediano que puentea las ciencias sociales y físicas ofrece ideas sobre las formas en que las políticas neoliberales son sentidas por las mujeres al Inicio de su Carrera Académica (ICA). Utilizando un modelo de curso de vida, este estudio presenta los resultados de un taller que buscó explorar las maneras en que las mujeres geógrafas, en Suecia, perciben y experimentan obstáculos en su avance profesional y qué estrategias de enfrentamiento implementan para superarlas. Los resultados muestran la confusión del trabajo y la vida privada al ICA. Encontramos que las experiencias del ICA en los departamentos de geografía suecos son consistentes con las de las mujeres en otros países. Llegamos a la conclusión de que el ICA supone cargas extra en sus trayectorias de carrera como académicas debido a los ambientes de trabajo cada vez más neoliberales, la falta de tutoría, y una creciente presión para producir productos medibles, así como un empleo precario. Argumentamos que las iniciativas y programas encaminados a retener a las mujeres en el mundo académico necesitan adoptar una perspectiva más amplia que reconozca los conflictos en las esferas privada y pública de las mujeres.

Palabras clave: Geografía, mujeres al inicio de su carrera, universidad, neoliberalismo, Suecia.

\section{INTRODUCTION}

Managerialism, heightened competition for funding, increased teaching and administrative workloads, short-term and fixed-term contracts have signaled in the recent years as neoliberal trends that characterize universities' current policies and practices (Beck and Young, 2005; Canaan and Shumar, 2008; Davies and Petersen, 2005; Gill, 2012). Several authors have argued that these practices are particularly detrimental towards women, who tend to bear the heaviest teaching and administrative loads at the expenses of their research productivity and their success in acquiring research funding (Archer, 2008; Hawkins et al., 2014; Clegg, 2013; David, 2014; Davies \& O'Callaghan, 2014; Joseph, 2014; Swan, 2010). Generally, women in science face major hurdles in their career advancement due to the masculine, middleclass and white character of university culture (Bagilhole and Goode, 2001; Gill and Donaghue, 2016). The current neoliberal restructuring of knowledge production has triggered renewed job insecurity and precariousness which affects women in ways so that the so-called phenomena of the "leaking pipe" appears to be on the rise again (Bagilhole and Goode, 2001; Wainwright et al, 2014).

In the 1980s, women geographers, in Spain, were exceptional in terms of number and engagement in the discipline. However, in the last decade the enrollment of women in geography $\mathrm{PhD}$ programs has slowed down implying that the number of women professors will not grow in the future either. Women have remained a minority in geography departments across Spain suggesting it is now a more male dominated discipline than it was in the 1980s; surprising given Spain had a higher number of women geography professors than the UK in the 1980s (Garcia Ramon and Pujol, 2004; Garcia Ramon, Ortiz, Pujol, 2009). Although an improvement in gender imbalance has occurred in the UK, men do still dominate the subject in the UK. In fact, while female PhDs in geography have gone up from $31 \%$ to $50 \%$ from 1978 to 2013 , a survey with a focus on post-PhD careers showed women are overrepresented in the 
junior positions, where more stress is reported due to difficulties in reconciling child and elderly care with work. These stresses are identified in the research despite women downplaying or avoiding mentioning their caring responsibilities in order to neither jeopardize their credibility nor the perception their peers have of them in the workplace (Maddrell et al., 2016). Building on these two studies, we focus on Sweden, a country often depicted as a global leader in gender equality policies (Mählck, 2013). According to the World Economic Forum's Gender Gap Index 2015, Sweden is ranked $4^{\text {th }}$ in the world as the best place to be a working women and, more significantly, it has achieved almost total equality in education rates.

Against this backdrop, we ground our study on an investigation of early career women (ECW) geographers in Sweden to investigate ECW's perceptions of factors enabling and limiting them through their career advancement. Geography covers both the social and physical sciences; the first being often female dominated and the second being generally male dominated; a mix which brings more perspectives into our case study. Additionally, geography as a middle sized discipline, like many others in the social and hard sciences, can be representative with regards to the trends engulfing academia at large (see also Garcia-Ramon, Ortiz, Pujol, 2009). How women fair in terms of career advancement within geography has been at the center of studies in Spain (Garcia Ramon and Pujol, 2004; Garcia Ramon, Ortiz, Pujol, 2009) and in the UK (Maddrell et al., 2016; Mahtani, 2014).

Geography, in Sweden, has had a relatively strong historical relationship with gender and feminism and had one of the first women professors in the country (Schough, 2002). Notwithstanding that the number of female geography PhDs has been going up in the last decades, we investigate how different factors have enabled and limited women during early career stages in Swedish geography institutions. The aim of this study is to examine the complexities of women geographers' experiences as situated actors in a neo-liberal work place.

We analyze these complexities of ECW experiences through a qualitative study to further the discussion on how women perceive obstacles and activate coping strategies in neoliberal academia. The article begins by examining constraints and opportunities in career paths in the neoliberal university system and, specifically, within the Swedish context. Turning to our empirical material, we outline the life course methods used in the workshop to explore the experience of ECW in Sweden. The findings are presented in five themes: mobilities and immobilities, precarious employment, supervisors, life outside academia and personal ambitions. We conclude by contextualizing the results within the broader discussions of career trajectories and neoliberalism in academia. From this, we propose some means to tackle the challenges women face at the department and/or institutional level.

\section{EARLY CAREER WOMEN ACADEMICS IN THE NEOLIBERAL ACADEMIA}

The neoliberalization of universities has had several consequences for women in 
the early stages of their careers during and post-PhD education. The number of publications on this topic has been growing in the last decade conveying the growing performance pressure that characterizes the ongoing neoliberal restructuring of academia (Davies and Bansel, 2005; Archer, 2008; Clegg, 2013; Hawkins et al., 2014; Alemán, 2014; David, 2014; Davies and O'Callaghan, 2014; Joseph, 2014; Lund, 2015).

Neoliberalization of universities means, in fact, declining resources and increased performance quantifiable rubrics; e.g. number of degrees awarded, students supervised, articles published and grants received. Research, in this context, becomes oriented towards the production of outputs in the form of articles, books and grants at the expense of time devoted to teaching, thinking and reading. The growing pressure to write is directly relational to the diminishing time to read. This has gendered consequences for woman rooted in everyday work norms and practices which are shaped by power practices, especially at the disciplinary level (Bryant and Jaworski, 2015). As universities become part of the market economy, the competition for research funding gets acuter and what is believed to be unproductive is discarded. Yet so-called unproductive tasks remain and fall into the realm of early career researchers. Gender roles become replicated and reproduced in tasks and responsibilities, e.g. teaching, caring work with student, committee work, with the consequence of women providing more of this labor.

Doctoral candidates and ECW are not divorced from the consequences of neoliberalism and, as gendered and embodied practitioners, they still must function as novice-expert; learning the academic trade while balancing other substantial responsibilities (Kamler and Thompson, 2008). This mix of complex tensions leads to the principle of "survival of the fittest" which heightens antagonism between individuals and institutions (Davies and Bansel, 2005; Lund, 2015). Emphasis is placed on being the "the academic superhero," a mobile person, always on top of things in administration and grant writing and providing an endless stream of publications (Pitt $\&$ Mewburn, 2016). The academic superhero is couched in masculinist normative characterization that places emphasis on particular employee settings, for example, being mobile and able to work full-time (González Ramos and Verges Bosch, 2013).

In this context, women tend to fair worse than men due to competing demands on the home and on the work front. Academic work is often flexible meaning women can combine housework, caring responsibilities and work. Flexibility can be seen as an advantage, but it can also be annexed by their partners' career needs, who may expect women to prioritize most of the caring responsibilities (Lund, 2015).

To be considered a successful scholar, in a neoliberal context, it is crucial to maintain a clear research trajectory and not have any blank spaces in one's CV. This requires women to adopt "have it all" coping strategies: e.g. they take their children to the field (Hall et al., 2002; Drozdzewski and Robinson, 2015), they wait until tenure to have children; they do not have children at all; they work more part time than men do; they sleep less; and they hide their caring responsibilities so as not to be considered less serious scholars (Hall et al., 2002; Klocker \& Drozdzewski, 2012; Lund, 2015). Women are more affected by families in their ability to move, and so must adopt 
alternative strategies (Shauman and Xie, 1996). Additionally, because female geographers engage in research focusing on topics considered "less scientific" such as community politics, feminism and social services; they are generally evaluated against more rigorous parameters. Such attitudes against women geographers are directly correlated to the discipline's position within a white male sphere (Hall et al., 2002). Women report adapting these norms through "right" clothes and using the "right" tone in conversations to avoid being perceived as threatening to men (Husu, 2010). In this context, it is not surprising women scholars are more prone to illnesses and stressrelated diseases (Hall et al., 2002; Davies and Bansel, 2005; Klocker \& Drozdzewski, 2012; Mountz, 2016).

To cope with these mounting challenges, often exacerbated by the lack of support at work, women rely on their families and friends to find support not to leave academia (Husu, 2010; Davies and Bansel, 2005; Parizeau et al., 2016). Moreover, they put in place personal mindfulness strategies to avoid burnout such as yoga, meditation, and exercise, among others (Davies and Bansel, 2005).Technologies, in the form of apps, can be helpful tools for creating mindfulness and to improve time management. However, they create an illusion of a stress-free environment and the possibility to work whenever one has five minutes at hand. However, they can be another means exercised by universities to scale back and outsource employees' wellbeing expenses, while increasing work intensification and control (Davies and Bansel, 2005; Gill and Donaghue, 2016).

Most existing literature focuses on the general trend of neoliberalization in academia and how this affects women. However, there persists a need for more empirical research, at the departmental level and disciplinary level, to can highlight the actual conditions of women and how they can be ameliorated (Dahlerup, 2010). This is accomplished by focusing on a middle size discipline, such as geography in Sweden, which is well-regarded for its gender equality (Mählck, 2013). In the next section issues surrounding women in Swedish academia are examined.

\section{SWEDEN: GENDER EQUALITY IN ACADEMIA?}

Unlike many countries, regular salaried employment with pension, health benefits and parental leave is the most common form of structuring doctoral programs in Sweden. Scholarships, as a funding model, have been phased-out in the past years, resulting in reduced admission, lower dropout rates, shorter study times, and better supervision. Nevertheless PhD candidates, particularly women, encounter a number of challenges during their programs, creating a stressful and unhealthy educational experience.

Following a relative secure period during $\mathrm{PhD}$ studies, new $\mathrm{PhDs}$ find themselves in a job market where the tenure track system is not in place (GU, 2012). Although the government has encouraged the establishment of such academic career paths, universities have been resistant to implement tenure systems as it demands more expenses on their part (SULF, 2014). Job security is reached on average seven years after the completion of the $\mathrm{PhD}$ if the candidate has managed to stay in the academic 93

Investigaciones Feministas

Vol. 7 Núm 2 (2016) 89-113 
pipeline through grant funding and teaching and if a lecturer position is advertised. Often these positions are highly coveted as there are few geography departments in Sweden. Adjuncts, short project funded and part-time positions have been flourishing as a result. Sweden, being somewhat small and having a relatively low number of research-tier universities, finds competition for advertised posts to be vigorous and often a lecturer position can only be achieved several years after getting a $\mathrm{PhD}$ (Elf, 2015).

Since the 1960s and 1970s when women started entering the universities in increasing numbers, research agencies started devoting their funds to research on women, gender roles and gender. In the 1990s women's equal inclusion in the university sector was legislatively encouraged, by setting objectives to recruit women professors (Bondestam and Grip, 2015). Despite these initiatives, a recent report from the National Gender Secretariat (Bondestam and Grip, 2015) highlights that women are penalized during research funding distribution not just from national funders, but also from international funders. Gender emerges as a biased indicator for how scientific quality is judged by funding agencies. Knowledge about how this ranking is opaque (Bondestam and Grip, 2015; Powell, 2016). An example given in the report of how a gender biased culture is intrinsic in some funding agencies is that women are more often judged as "good scientists" while men are defined as "brilliant scientists" (Bondestam and Grip, 2015). Moreover, the report shows the recruitment of personnel, differences in salary, employment conditions, career development, maternal leave and sick leave are all indicators showing women's working conditions within academia are poorer than men. Women suffer a cumulative negative economic effect: e.g. they take more maternity leave and work more part-time which leads to lower wages. Women scholars have lower salaries than men because they take up heavier administrative and teaching loads, while men focus more on grant writing and publications. At the same time, women seek less funding than men and for lower sums. Defined as less ambitious or brilliant by some reports (Bondestam and Grip, 2015; Leslie et al., 2015), women appear to be victims of the "impostor syndrome": valuing themselves lower than what they are actually worth and what their accomplishments demonstrate.

Powell (2016), author of a recent $\mathrm{PhD}$ thesis on gender and meritocracy in one of Sweden biggest universities, underscored that work on gender equality in academia is decentralized and outsourced to external agencies and committees, rather than being addressed at the department level. This stands in contrast to Swedish debates in the public sector with a strong emphasis on workplace gender equalities. Women in academia are few and discriminated against due to a lack of clarity existing around recruiting and funding processes (Powell, 2016). This difficulty in career progression for women scholars emerges in the data gathered at Stockholm University showing a $13 \%$ reduction between women $\mathrm{PhDs}$ and lecturers and a $42 \%$ reduction from women lecturers to professors in Social Science (CDR SU, 2015).

Adding an intersectional perspective, a growing number of foreign women academics are now working in Sweden. The Swedish higher educational system has, in fact, undergone major structural changes in the last decades: international $\mathrm{PhD}$ students, (the majority men) make up $31 \%$ of the total and $50 \%$ of those doing their 
$\mathrm{PhD}$ in technical subjects come from Asia (Mählck, 2013). Integration barriers for academics in the Swedish job market exist and are acute in a neoliberal structure. It has been estimated it takes seven years for foreigners with a higher educational level to get a job corresponding to their qualification (SACO, 2013). Moreover, according to Sveriges Internationella Talanger (SIT, 2014), an NGO supporting academic immigrants in Sweden, newly arrived immigrant academics find it difficult to enter into the universities due to a lack of networks. To thrive in Swedish universities, foreign employees have to: publish and acquire proliferous funding, align themselves with the Swedish work routines and culture and most importantly, speak Swedish so as not to be excluded from the social and work environment. Thus other social categories can add additional barriers to accessing Swedish work place norms but remain under explored in internationalization strategies proposed by the higher educational sectors (Los Reyes, 2009; Mählck, 2013).

Sweden has a strong reputation internationally for promoting gender inequality in both institutional and daily life however; the reality is a complex practice of gendered relations (Martinsson et al., 2016). Literature on the academy reveals cracks to system as the capacity of the welfare state and other supports give way to the pressures of neoliberal norms. Thus geography is an interesting case, due to its position as middle size discipline, to explore the ways neoliberalism is felt by ECW.

\section{METHODS}

Early career women are ideal for understanding the impacts of neoliberalism in the university. They are at the forefront of changes in career trajectories and thus their experiences are indicative of the impact of neoliberalism 'on the ground' in departments and within a discipline. In order to learn more about the experiences of ECW in geography, we designed and implemented an intensive and interactive workshop. The workshop was held on a weekday late afternoon at [name withheld for peer review] University at the Department of Human Geography. ECW, namely PhD candidates in the late stage of their theses to those up to ten-years past their defense, from the host department and other departments within the greater urban region were invited. Women were contacted through email, related professional list serves, Facebook and through personal contacts. Participants were selected based on their affiliation with geography and related institutions. The workshop lasted for two hours and a light snack was served to the nine participants. The workshop was held in English to accommodate as many backgrounds as possible.

The workshop was designed to focus on the life course of women academics. We chose to focus on women's life course as it is documented women underplay the impacts of their personal lives when discussing their careers (Maddrell et al., 2016; Parizeau 2016). As non-privileged actors in academia along with substantial changes in life courses, for example having children provides a broader perspective which contributes to more nuanced understanding of the career trajectories of the women.

Life course is a narrative interview technique that stresses personal histories as a means of observing linkages and tensions between individual actions and social 95 
structures (Verd and Andreu, 2011). Due to its bibliographic character, the life course provides a framework for including multiple perspectives (Kulu and Milewski, 2007). The life course approach builds upon the respondents' told life stories and should be situated within the context of the individual, location in time and place, linked lives (different actors), timing (both large social events or individual and life space (Elder et al, 1993; Giele and Elder, 1998). The aim of using this approach was to create a space for women to discuss the role of their personal experiences on their academic careers without fear of jeopardizing their professional image. Moreover, hearing each other's life stories, created a shared experience of similarity and difference to promote understanding between the women. Drawing generalizations from life course is a limitation of the method when using only qualitative data (Verd and Andreu, 2011). Moreover, life course may over emphasize individual struggles within a structural context (Hutchinson, 2008). Nonetheless, the diversity of experience emphasized by using women's voices in academia contributes complexity to the growing body of work on gender and neo-liberalism in universities.

The workshop consisted of four components. The first component focused on life course narratives. Women were partnered to describe their life story to their party and at the same time create a poster outlining major self-defined life events. Reconvening in a large group, we shared our life course posters and displayed them. In the second component, we identified different trigger points in the individual life course that enabled or blocked different outcomes and trajectories, for example, being admitted or denied entry into a $\mathrm{PhD}$ program. The events in the life course were marked by sticky notes arrows and discussed collectively.

During the third component respondents were divided into small discussion groups where the themes that emerged during the enabling/barrier discussion in detail (career trajectories, personal life and working environment) were deliberated. This steered us towards the more structural elements of daily work but relied heavily on the life courses we had shared earlier in the workshop. The final part of the workshop was reflective and dealt with our experience and learning outcomes from the workshop.

The workshop was recorded and transcribed. Transcriptions were analyzed according to life course principles (Elder et al, 1993; Giele and Elder, 1998). This entailed examining and placing life courses within the academic institutional and social structure and analyzing the women's experiences thematically. Themes were identified through the literature and previous studies, as well as through themes which the respondents identified during the life course. This process differs from discourse analysis through analyzing individual experiences rather than collective representatives. The themes reviewed in the result section emerged from the combination of life course events and subjects which dominated in the discussions.

The workshop generated rich, detailed data demonstrating the intersection of personal experiences with academic structure. A limitation to the workshop lay in the size of the geographical community in Sweden. Many of the women knew, or knew of each other, and while the feeling of the workshop was supportive, perhaps a larger community base may have invited even more detailed results. This also required ethical care; women could be identified easily through other indicators than name and 
location; for example, hobbies or interests and through year of attainment of $\mathrm{PhD}$ as it is not unusual for relatively small departments in Sweden to only have one or two $\mathrm{PhDs}$ defending any given year. Thus, extra care to protect anonymity through generalization was required. Moreover, given the analytical competency and research experience in the room, there was a tendency by the participants to analyze and extract meaning from the data as it was being produced through the workshop. Nonetheless, the experiences derived from a life course perspective are important to understanding how this large social science field supports or blocks women.

The workshop consisted of 9 ECW active academics working in both human and physical geography (See figure 1 for a summary). The women ranged from $30-42$ years of age. There were a variety of backgrounds in the workshop, four women were Swedish and five were foreigners. Seven of the women had no children and two had families. The majority of the participants had travelled to multiple countries as part of their education. Five of women had completed their PhDs, two were in their final years, and two were mid $\mathrm{PhD}$ education. As a side note, there were five women - who were post- $\mathrm{PhD}$ - who indicated that they wished to participate but were unable to do so due to stress and child-care limitations. This signals the challenges around gathering together women at this stage of career and life course. Due to the diversity within this small sample, the results were representative of breadth experiences of early career researchers.

Figure 1: A summary of workshop participants

\begin{tabular}{|c|c|l|l|c|}
\hline Participant & Career stage & $\begin{array}{l}\text { Citizenship } \\
\text { status }\end{array}$ & $\begin{array}{l}\text { Family } \\
\text { background }\end{array}$ & $\begin{array}{c}\text { Number of countries } \\
\text { related to education }\end{array}$ \\
\hline W1 & $\begin{array}{c}\text { PhD } \\
\text { Candidate }\end{array}$ & non-Swedish & partner & 6 \\
\hline W2 & Post-PhD & non-Swedish & partner & 3 \\
\hline W3 & $\begin{array}{c}\text { PhD } \\
\text { Candidate }\end{array}$ & non-Swedish & single & 2 \\
\hline W4 & Post-PhD & $\begin{array}{c}\text { Dual Swedish } \\
\text { Citizen }\end{array}$ & $\begin{array}{c}\text { partner with } \\
\text { children }\end{array}$ \\
\hline W5 & Post-PhD & Swedish & partner & 2 \\
\hline W6 & $\begin{array}{c}\text { PhD } \\
\text { Candidate }\end{array}$ & Swedish & partner & 2 \\
\hline W7 & $\begin{array}{c}\text { PhD } \\
\text { Candidate }\end{array}$ & non-Swedish & partner & 2 \\
\hline W8 & Post-PhD & Swedish & $\begin{array}{c}\text { partner with } \\
\text { children }\end{array}$ & 3 \\
\hline W9 & Post-PhD & Swedish & single & 1 \\
\hline
\end{tabular}




\section{RESULTS}

During the workshop the intersection of personal lives and academia work permeated throughout the entire discussion. The following section presents five themes that emerged during the workshop. While having divided the results into thematic categories, it should be evident they overlap and thus the material and content of each should be seen as connected and interwoven with other result categories.

\subsection{MOBILITY AND IMMOBILITIES}

During the workshop the intersection of personal lives and academia work permeated throughout the entire discussion. The following section presents five themes that emerged during the workshop. While having divided the results into thematic categories, it should be evident they overlap and thus the material and content of each should be seen as connected and interwoven with other result categories.

Without exception the women had been mobile - domestically, within Europe and internationally - to attend to their education or to engage in international experiences which fundamentally shaped their career trajectories. These experiences stood out in the life course narratives as significant events changing life course trajectories or introducing the women to new fields of science and direction.

"I went to [European country] for a summer course which was an important thing for me personally to go to [European country] because that is what guided my way forward and it's a country that I have gone back to always" (W9)

Movement was often described as related to personal goals such as joining a partner, adventure or life style. In many ways, academia, especially early in the research career, served as a way to meet needs of personal life rather than the needs of one's career.

"I was actually accepted into two programs but the other one was in [place name withheld] and I decided I wanted to get the hell out of there" (W3)

Nonetheless, mobility, work goals and personal needs were often interchanged. For some though, mobility was becoming a burden and challenge to their emotional well-being and sense of personal stability.

"It feels like it is a bigger choice than just do I want to continue in academia or not? Because academia itself I would like to continue this kind of work but I think it always come with a lot of things and moving. And I've been moving a lot..." (W1).

Movement and the constraints around movement, for example, housing arrangements, residency, health insurance and so on, shaped and informed decisions to move or to stay. 
"I couldn't get some kind of sick leave percentage due to residence permit which I have to renew every year so it is like I have to be physically here or if I go back to [country of origin] to finish I have to be, to have a job" (W2)

The women also discussed different kinds of mobility such as moving in- and outof the research process due to illness or other kinds of leave affecting their approach to research and their career paths. In some instances, it changed the research significantly.

"When I came back to work in 2015 [after a lengthy sick leave] I completely changed my thesis topic" (W3)

The participants agreed that movement was a necessary career move and yet often stood in conflict to personal lives. However, even when the option to promote career through moving was available, this was often divergent with family needs. The tensions between career and personal needs were at the fore of the discussion. A number of personal life factors emerged influencing whether someone could move included family, home ownership, pets, activities and even whose turn, in the family unit, it was to move or seize the opportunity.

"It is a very flexible post-doc. I can be anywhere in the world but I also have a house with [pets] so I am kind of territorialized in terms of my private life" (W5)

The tensions between mobility and immobility shaped the women's life story narratives. Movement simultaneously provided opportunity and flexibility, they described, while also hindering their career trajectories and plans.

\subsection{PRECARIOUS EMPLOYMENT}

Following the relative security of $\mathrm{PhD}$ employment in Sweden, uncertainty of current and future employment arose as a shared experience almost immediately in the workshop. The women described earning a living, working project-to-project or teaching semester to semester. Opportunities arose for the women but the steadiness and security many women desired was difficult to find.

"In 2015, I defended my thesis finally and I was very lost after that what to do, to continue with life and have a lot of uncertainties or ...but I got a kind of temporary employment last year and this year teaching but meanwhile applications, so we'll see what happens, maybe here next year or maybe not! " (W2)

Materializing from the discussion was a tension between job security and jobs that were stimulating and flexible. The women discussed to what extent they were willing to accept and adapt to insecurity for the rewards of research.

“... if I could get a safe job somewhere else, a safe and fun job as rewarding or as not rewarding, yes rewarding for your personal sake, somewhere else, I would of course go for that" (W6)

There was a lack of consensus amongst the participants that precarious 
employment was entirely negative. Some women described enjoying the shorter hours, the flexibility and the ability to pursue other activities; for example having a side business.

"For me it is alright with the uncertainty, I mean it is stressful but its part of the

freedom as well. I am not really stuck. Because now I have, during this spring, I had $100 \%$ employment and that's kind of stressing me out so I have short-term or $25 \%$ so I can do other things." (W8)

The participants did agree that precarious employment was part of the process of becoming an academic yet the balance in terms of costs were an important factor that they always considered.

\subsection{SUPERVISORS AS EMBEDDED GATEKEEPERS}

Supervisors were brought forth as the primary relationship in academic progress. The participants described meeting, being inspired and challenged by different supervisors throughout their careers. The influence of supervisors triggered advancement into academia.

"So one enabler was that the discussions I had with [professor's name withheld] that later became my supervisor before I started my PhD. That's kind of when I got the idea that I could to do a $\mathrm{PhD}$. So he was very important, I just came here and talked to him, one time each month or so. So he gave me a lot of time so that was great" (W9)

Supervisors were described as gate keepers along the path to different parts of the academic career and this relation continued in importance before, during and after the $\mathrm{PhD}$ education. The supervisor role shifted at different stages of the $\mathrm{PhD}$ education, but their ongoing support and advocacy (or conversely blocking) remained important. The supervisor was not only important in the internal university network but also played an important role in launching women into other institutions, networks or workplaces outside of academia changing career and life patterns.

"The networks that my supervisors introduced me to outside of my department were super crucial" (W4)

The life course narratives showed the relationship between the $\mathrm{PhD}$ candidate and supervisor continues in importance beyond the educational phase. The relationship with supervisors often created opportunities for these early career researchers.

“... I also co-authored, I wrote an article with my former master's supervisor that was published in 2010 .... So I was here for 5 years doing this thing $[\mathrm{PhD}]$ and I learned afterwards that it was this 2010 publication that was accepted in 2009, late 2009 or something, was actually the thing that kind of got me into the program so it was a previous publication, it was what was needed"(W5)

Through the discussion women were aware of the nuance of gender in the role of 
supervisors and their power in the broader academy: "The right male professor opens more doors" (W6)

While women did not describe placing gender above having excellent knowledge and research skills, they did describe how gender shaped the relationship and expectations in role-modeling successful academic work. The workshop participants described being inspired by women in higher positions within the academia, while being aware of the broader structures at play.

"But every time I see a successful male professor, I am thinking about who is taking care of his family ... I need to see a woman doing that to know that it is possible" (W8)

It emerged that the supervisory relationship was a professional relation yet the relationship was embedded into one's personal life and sense of success. Moreover, women were aware of homosocial practices in these relationships and how these extended into their departments and networks as well as the importance to conform to feminine norms in order to pave the way for a career in academia.

\subsection{LIFE OUTSIDE OF THE ACADEMICA}

Unsurprisingly family, both nuclear and extended, along with children emerged as a factor shaping career trajectories, mobilities and decisions that women make as they steer their life course. Partners emerged as an important factor in career trajectory, particularly in relation to movement to new cities or countries.

"My husband got a job in Stockholm so we moved to Stockholm and that is my link to the university. I was sitting here as a guest researcher for a year" (W4)

Partners' influence was also seen through financial supports and familial structural networking and shared domestic activities.

"In 2011 when I realized that I wanted to [finish my $\mathrm{PhD}$ as] time was running out and I had to finish my project. We had to get a nanny to take care of the kids. So I could finish my $\mathrm{PhD}$. "(W8)

Families were not just factors in determining career path opportunities, locations or time restrictions. Families provided important emotional care. Support was found in parents, siblings and other familial networks were essential to the emotional work of being an early career academic: "My mother, she is kind of everywhere!" (W1)

"My sambo [common-law partner in Swedish] started with me when I had the biggest crisis so I think family support. It would be impossible for me to finish without him both emotionally and financially" (W2)

Yet at the same time, family expectations created stress and anxiety, some women indicated. There was pressure to finish and 'be successful' in complicated ways that 
went beyond career. There was pressure to have children, to be a good mother and other aspects particular to being a woman. The women, between the ages of 30 and 42 , discussed what expectations were on them as an embodied person both in the workplace and at home.

"I think age and this stress, what you think a woman should do and at what age played a role for me" (W2)

However, the discussions revealed it is not only the immediate family which played an important role; friends and personal networks situated elsewhere in academia, in other universities or departments, emerged as an important part of the education and career process. Friends served as triggers to move to another university, as information networks, informal knowledge exchange on university bureaucracies and most importantly as inspiration. The woman cited many people who had succeeded as a driver for their own decisions. These broader networks near the academic setting but in different professional communities highlighted the significance of different kinds of relations.

"What really enabled my work was the academic surrounding that I was in. My partner is a head of a department in [place name withheld] university, my sister did her $\mathrm{PhD}$ thesis at the time and I had many friends who were in the setting so we discussed a lot like how you should go about this" (W5)

The extent and reach of social networks in the private sphere reveal how academic pathways for ECW are tied to their personal spheres. For many women at the workshop, these networks were positive but, at times, additional stresses emerged from them. The results show that career and personal life are intertwined in such way it is hard to separate family and institutional structures: "It is not only a career choice but it is life inclusive" (W1)

\subsection{AMBITIONS AND CHALLENGES}

A final but significant theme which materialized was the characteristics of the participants in their own words: ambitious, hard-working, strategic and stubborn! The women articulated that pursuing an academic career is worthy because it is satisfying, interesting and they enjoyed the pursuit of knowledge. Nonetheless, staying in academia was not taken for granted by any of the participants. Each woman felt they had fought and struggled to acquire and maintain their positions.

"You have to be a bit bold to really pursue this path ...I am going to gamble a bit, because it is a bit of gamble "(W6)

Often fighting to stay in the discipline came in the face of direct opposition or discouragement. Several women cited examples of academic leadership discouraging them or in some cases blocking their way forward. These situations either led to nonsuccess or drove the women into action either in that department or an alternative location. 
"Maybe this is just because I am weird, but I an enabler for me was people discouraging me ... I was kind like screw you, I'm going to do it anyways (laughs) so maybe that's just ambition!"' (W3)

These experiences were described as emotive and responses were related to a sense of self. At the same time, women felt stressed, panicked and in competition with others. There were feelings of inadequacy and uncertainty despite clear proven successes.

"Feeling permanent panic and depression at realizing I am not as good as I thought because everyone was so brilliant." (W4)

Despite these feelings, the women commented on their perseverance. The articulation of strength and ambition was quite strong despite failures, setbacks and other challenges the women spoke quite openly about. Feelings of pride in their work and a sense of accomplishment were important and emergent themes which illustrated, through the narratives, the intersection of the public and private spheres in women's academic lives.

\section{DISCUSSION}

Results from the workshop demonstrate women's private and academic lives are tightly enmeshed in the public and private spheres and aspects which enabled their careers can simultaneously act as hindrances. The following discussion mirrors the themes that emerged of the previous section.

\subsection{NEOLIBERAL MOBILITIES: A REQUIREMENT AND/OR A CHOICE?}

Work experience gained abroad has become a not-so-subtle requirement within academia in order to acquire a fixed position (González Ramos \& Verges Bosch, 2013). The great majority of women in our sample had moved between countries for their education, which they recognized as a great source of inspiration, learning and motivation to continue their academic journey. However, as they move through their own life course, their feelings regarding mobility changed. For some following their $\mathrm{PhD}$ education mobility was not necessarily any exciting opportunity. Several acknowledged that the process of moving is demanding on the personal front when one is single, let alone when one has to move her family or leave networks behind her.

Often women in our sample were in a stable relationship and their partner had already a fixed position or they had children, which made them comparatively fixed spatially. Understandably, they did not want to uproot their children from their everyday environment nor place their families' financial security in jeopardy for a period abroad when they were unsure a fixed appointment awaited their return. As highlighted by González Ramos and Verges Bosch (2013) balancing career and family 
involved difficult choices and substantial trade-offs between the two. Moving meant early career researchers had to balance a new job and a new daily routine for their families, which would be an added burden to their already prominent caring responsibilities. This situation can place more demands on women than on men as often mobility schemes are designed around masculine practices without taking into account the existence of a family behind the mobile academic (Shauman and Xie, 1996).

Childbearing, and especially the timing of it, was also consistently brought up by women, even by those who did not have children yet. Constrained by their uncertain careers and their biological clocks, they debated when the right time to have a child would be, acknowledging at times the pressure they were under due to their partners' and general societal expectations. Thus, personal choices become embedded in the neo-liberal structure. This worry resounds in the literature (Klocker \& Drozdzewski, 2012) where waiting to have children after the attainment of tenure was singled out as a common coping strategy for women in academia.

Those women in our sample who had a foreign background spoke of their adaptation and integration process in Swedish academia as a challenging and, aware of the difficulties they had faced, they felt uncertain about relocating once again. They had been resourceful in aligning themselves to Swedish academic routines, language and work ethics in order not to stand out as migrants and foreigners. Foreign ECW did not perceive diversity as a positive or valued attribute in an academic setting (Los Reyes, 2009: Sang, Al-Dajani, Özbilgin, 2013; Mählck, 2013). Hence, having to adjust again with a family in tow was seen as a less attractive option, especially as it is seldom a long term solution, but rather a fixed term appointment, such as a Postdoctoral fellowship.

These findings suggest a tense relationship between personal and professional needs. These tensions, while not new to women in the workplace, may be exacerbated in a neoliberal context where support structures, permanent employment, and transparent career paths are eroded. For vulnerable workers, such as ECW and other non-normative conforming workers, these tensions may be felt more acutely.

\subsection{PRECARIOUSNESS: IS IT WORTH THE TROUBLE?}

In part of because of these tensions, women in our sample described themselves as "realistic". Everyone is our sample was aware of the detrimental consequences of precariousness, either because they had experienced stress and burn-out themselves or because they had seen their colleagues getting sick. In the literature (Gill, 2012; Gill and Donaghue, 2016), women referred to chronic stress, anxiety, insomnia, hurtful comments by reviewers, supervisors and peers and pressure to deliver by supervisors. Fear of burn-out led many women to seek coping strategies including mentorship and support networks.

As a result, they were open to other employment opportunities, as they were 
aware of gender biased employment practices supported by homosocial networks in academia (Rice, 2012; Richman, 2013; Williams et al., 2014; Milkman et al., 2015). Additionally, while flexible working hours were seen as functional in balancing family and work, it also meant a heavier burden due to their partners' perception that they would "do it all" (see also Hall et al., 2002; Drozdzewski and Robinson, 2015).

Most importantly, women criticized the instability intrinsic to neoliberal academic employment frameworks, which are built upon continuous short-term teachingintensive contracts (Archer, 2008; Hawkins et al., 2014; Clegg, 2013; David, 2014; Davies \& O'Callaghan, 2014; Joseph, 2014; Swan, 2010), despite the acknowledgement that these contracts were vital for providing incomes while applying for research funding and other positions. This created a catch-22 for women whereby they needed and so took short-term contracts but this reduced time for productive activities, such as writing manuscripts, needed to get more stable employment opportunities.

Women, aware of their skills and talents, mostly described themselves as playing the game for as long as they could. They had few illusions of linear career paths under a neoliberal system forcing them to strategize and cope in response to the neoliberal structure.

\subsection{REPLACING FORMAL INSTITUTIONAL SUPPORTS WITH PERSONAL NETWORKS}

The findings suggest that under a neo-liberal structure, strategies are not centered on university or department structures; instead people and networks become the focus on women's coping strategies. Supervisors are one of the most important actors for ECW. They serve as mentors, gatekeepers, advocates and, in some case, as blockers. Regardless of the character of the relationship, our study suggests on-going relationships with supervisors are perceived as important to women in getting new employment after the $\mathrm{PhD}$ and for their mentoring and advising roles. This means supervisors can actively help place their former students in a position or provide the support and advice for gaining new employment. This finding is in line with other research which has shown that the intensification and proliferation of short-term employment requires support and mentorship (Gill, 2012). Many of the women in the workshop relied on this help following their PhD studies, but did find the relationship to be sometimes complicated with former supervisors leaving past students to fend for themselves (Golde, 2015). For ECW in Sweden, the end of the PhD education is a move from relative security with social benefits to insecurity and often coincides with the loss of many formal institutional supports. In the neoliberal context of precarious employment and mobility, as we discussed, the supervisor is an important anchor during uncertainties.

In some cases, supervisors can play an active role in this transition and beyond the $\mathrm{PhD}$ education period. Women $\mathrm{PhDs}$ may benefit more from supervisors who continue 
to maintain the mentoring relationship beyond the contractual $\mathrm{PhD}$ supervision (Archer, 2008). Our findings suggest supervisors may become more important as the $\mathrm{PhDs}$ launch their career, as opposed to the conventional wisdom. This could be even more vital in a setting where women are more discriminated against and considered less competent than their male counterparts (Moss-Racusin et al., 2012; Macoun and Miller, 2014). Women reported needing multiple supports in building a career. Thus, this relation walks a fine line between novice-expert, apprentice- teacher among other aspects. While it is hard to suggest solutions to the complex relationship which bridges an expanse of time in $\mathrm{PhDs}$ lives, it is clear the relationship is an important factor in determining career paths both within and outside of the academia. This offers established scholars an opportunity for resistance against the pressures of neoliberalizing academia.

Our findings support the notion that supervisor's impacts were more strongly felt beyond the research product and lay in the process of becoming a scholar (Kamler and Thompson, 2008) suggesting a shift in the role of leadership in a neoliberal context. Following this vein, ECW may need ongoing support in becoming a professional scholar, more than becoming a researcher. Mentors can and do serve this role. Nonetheless, while respondents in the workshop mentioned mentors, they did continue to fall back towards their supervisor as someone who knew their strengths, capabilities and interests over a significant length of time. It may be that for those with female supervisors this role-modelling could have extra benefit. This reveals a complicated relationship between women as supervisors and as $\mathrm{PhDs}$ where expectations go beyond the professional contractual obligations (Bryant and Jawarski, 2015). Of course, this could add an unfair burden onto female professors, who are, themselves, struggling in the neoliberal context. Care work and other invisible burdens on female staff raise moral questions about the role of informal supports in neoliberal academia. These results show how academics, in the neoliberal context, may be externalizing work place supports.

Externalized networks and supports materialized as an essential support for ECW to navigate a neoliberal system. As discussed, the supervisor within the university was often the root of the network internally; however, the life course analysis showed other types of networks were significant for women. These networks include family, partners, and most significantly friends. These networks were important in developing coping strategies for managing private lives; for example, child care providers (Aand Al-Dajani, Özbligin, 2013) and they also were essential in mitigating feelings of stress, isolation and inadequacy (Hawkins, Manzi, Ojeda, 2014). Our findings demonstrate the female networks of friends encourage, support, and even role model successes, were important sources of inspiration and learning for women pursuing career pathways. With the rise of insecure and short-term employment in a neoliberal context, these external networks may be the foundation of stability and support for many women.

Despite the prominence of these networks they were often invisible and occurred behind the public façade of academic work. Informal support networks and strategies 
remained hidden as women feared to be seen as unprofessional or unable to cope (Winkler, 2000). Our study shows ECW rely heavily on support networks in multiple capacities to accomplish day-to-day tasks as well as for knowledge and emotional care. Even though Sweden is a leader in structural supports for gender equalities and family friendly policies, the women reported struggling with child care and sick leaves. This reflects the neoliberal outcome leading to erosion of the capacity of supports and structures (Gill and Donaghue, 2015). This is not to suggest a monolithic neoliberal global work place, but it raises questions of how specific departments need to develop supports and engagement with emerging researchers as they establish themselves as professional scholars.

\section{CONCLUSION}

Our findings confirm that to be a good woman geographer in a neoliberal context is to walk a fine line between belonging, building relationships and fitting homosocial norms (Mählck, 2013). To overcome institutional obstacles women need to utilize coping strategies which conform to neoliberal rubrics and ideals by managing personal lives, such as child care, illnesses and stress- and work-related injuries so private spheres remain invisible. Concomitantly, for working women the flexibility of academic work days and even work cycles, the opportunities to pursue one's own interests, and build relationships with interesting colleagues provided women with options to pursue a stimulating career that perhaps could not be found in other sectors (Kern et al., 2014). Within these forms of insecurities, women found coping strategies and alternative pathways to success. What is noticeable about our results is women still carry extra burdens, exacerbated in the neoliberal context, even with the benefits of the Swedish welfare state and the beneficial $\mathrm{PhD}$ educational model.

Consequently, mentorship and support networks need to be optimized at the departmental level. Support practices need to be further investigated to assess which are successful and how they can better be applied to ECW's specific conditions. Against a meta-narrative of resistance of neoliberalization of academia (Macoun and Miller, 2014; Mountz et al., 2015), our study confirms the importance of peer solidarity and external support networks, but also surprisingly shows women's realistic and pragmatic attitudes towards their future career within or outside academia, reconciling family life and personal health.

Strikingly, during our workshop, the women praised their stubbornness and will power to overcome obstacles. Their love of research, interest at finding something new and interesting drove most of the women in their career pursuits. Each of the themes presented in our study reveal the line between the personal and professional is blurred and relational. Accordingly, the negatives aspects of academia often have a positive side as well. The life course suggests that expanding the discussion of women in academic experiences to their broader lives gives insights into how policies are felt and how far women are willing to sacrifice for academia. Women in the workshop revealed 
the complexity in discussing obstacles and coping strategies as experiences differed individually and shifts over the career trajectory. What is apparent, however, is that the dual character of enablers and barriers requires further investigation throughout career stages in academia.

\section{REFERENCES}

ARCHER, LOUISE (2008). The new neoliberal subjects? Young/er academics' constructions of professional identity. Journal of Education Policy, 23, 265-85. doi: 10.1080/02680930701754047

BAGILHOLE, BARBARA, \& GOODE, JACKIE (2001). The Contradiction of the Myth of Individual Merit and the Reality of a Patriarchal Support System in Academic Careers A Feminist Investigation. European Journal of Women's Studies, 8(2), 161-180. http://doi.org/10.1177/135050680100800203

BECK, JOHN, \& YOUNG, MICHAEL.F.D. (2005). The assault on the professions and the restructuring of academic and professional identities: A Bernsteinian analysis. British Journal of Sociology of Education, 26, 183-197. doi: 10.1080/0142569042000294165

BONDESTAM, FREDRIK \& GRIP, LOUISE (2015) Fördelning eller förfördelning? Forskningsfinansiering, jämställdhet och genus - en forskningsöversikt. Göteborg: Nationella Genus Secretariat.

BRYANT, LIA \& JAWORSKI, KATRINA (eds) (2015), Women Supervising and Writing Doctoral Theses: Walking on the Grass. Maryland: Lexington Books.

CANAAN, JOYCE.E, \& SHUMAR, WESLEY (Eds.). (2008). Structure and agency in the neoliberal university. New York, NY: Routledge.

CENTRALA DOKTORANDRÅDET (CDR) at Stockholm University. (2015). Postdoktoral karriär vid Stockholms universitet ur ett jämställdhetsperspektiv. Retrieved May 19, 2016, from http://www.chess.su.se/polopoly_fs/1.281812.1462806020!/menu/standard/file/po stdoktoral_karriar_vid_stockholms_universitet_ur_ett_jamstalldhetsperspektiv.pdf

CLEGG, SUE (2013). The space of academia: Privilege, agency and the erasure of affect. In C. Maxwell \& P. Aggleton (Eds.), Privilege, agency and affect: Understanding the production and effects of action (pp. 71-87). Basingstoke: Palgrave Macmillan.

DAHLERUP, DRUDE (2010), Jämställdhet i akademin. En forskningsöversikt. Stockholm: Delegation for jämställdhet I högskolan 
DAVID, MIRIAM E. (2014). Feminism, gender and universities: Politics, passion and pedagogies. Farnham: Ashgate.

DAVIES, BRONWYN \& BANSEL, PETER (2005). The Time of Their Lives?: Academic workers in neoliberal time(s). Health Sociology Review, 14(1), 47-58. http://doi.org/10.5172/hesr.14.1.47

DAVIES, BRONWYN \& PETERSEN, EVA.B. (2005). Neoliberal discourse in the academy: The forestalling of (collective) resistance. LATISS: Learning and Teaching in the Social Sciences, 2, 77-98.

DAVIES, HELLEN \& O'CALLAGHAN, CLAIRE. (2014). All in this together? Feminisms, academia, austerity. Journal of Gender Studies, 23(3), 227-232. http://doi.org/10.1080/09589236.2014.913824

DROZDZEWSKI, DANIELLE., \& ROBINSON, DANIEL. F. (2015). Care-work on fieldwork: taking your own children into the field. Children's Geographies, 13(3), 372-378.

ELDER JR, GLEN.H., KIRKPATRICK JOHNSON, MONICA \& CROSNOE, ROBERTT. (1993), The Emergence and Development of Life Course Theory in J. Mortimer \& M.J. Shanahan (eds.)Handbook of the Life Course. 3-19. New York: Kluwer Academic/Plenum Publishers.

GARCIA-RAMON, MARIA DOLORS, ORTIZ, ANA., \& PUJOL, HERMINIA (2009). Negotiating personal and professional lives: Women and men faculty in Spanish geography. Analele Universitatii Vest Timisoara, Seria Geografie, 19, 6780.

GARCIA-RAMON. MARIA DOLORS, \& PUJOL, HERMINIA (2004). Gender representation in academic geography in Catalonia (Spain): towards a masculinization of the discipline? Journal of Geography in Higher Education, 28(1), 111-119. http://doi.org/10.1080/0309826042000198684

GIELE, JANET. \& ELDER JR, GLEN. (1998) Methods of Life Course Research: Qualitative and Quantitative Approaches. Thousand Oaks, California: Sage Publications.

GILL, ROSALINDE (2012). The hidden injuries of the neoliberal university. In: RyanFlood, R. and Gill, R. (eds.) Secrecy and silence in the research process. 228-44. London: Routledge.

GILL, ROSALIND \& DONAGHUE, NGAIRE (2016). Resilience, apps and reluctant individualism: Technologies of self in the neoliberal academy. Women's Studies International Forum, 54, 91-99. http://doi.org/10.1016/j.wsif.2015.06.016 
GOLDE, CHRIS. M. (2014). The formation of scholars: insights of the Carnegie Initiative on the Doctorate. GeoJournal, 80(2), 209-213. http://doi.org/10.1007/s10708-014-9575-5

GONZÁLEZ RAMOS, ANA. M., \& TORRADO MARTÍN-PALOMINO, ESTHER (2015). Addressing women's agency on international mobility. Women's Studies International Forum, 49, 1-11. http://doi.org/10.1016/j.wsif.2014.12.004

GONZÁLEZ RAMOS, ANA.M., \& VERGÉS BOSCH, NURIA (2013). International mobility of women in science and technology careers: shaping plans for personal and professional purposes. Gender, Place \& Culture, 20, 613-629. doi: 10.1080/0966369X.2012.701198

GÖTEBORG UNIVERSITY. (2012). "Universitetet Har Ingen Plats För Unga Forskare - Medarbetarportalen." Accessed May 4, 2016. http://www.medarbetarportalen.gu.se/aktuellt/gu-journalen/arkiv/2012/nummer-212/universitetet-har-ingen-plats-for-unga-forskare/?skipSSOCheck=true.

HALL, JENNIFER, MURPHY, BRENDA L., \& MOSS, PAMELA (2002). Focus: Equity for women in geography. Canadian Geographer / Le Géographe Canadien, 46(3), 235-240. http://doi.org/10.1111/j.1541-0064.2002.tb00743.x

HAWKINS, ROBERTA., MANZI, MAYA, \& OJEDA, DIANA (2014). Lives in the Making: Power, Academia and the Everyday. ACME: An International E-Journal for Critical Geographies, 13(2), 328-351.

HUSU, LISA (2010). Sexism, support and survival in academia. academic women and hidden discrimination in Finland. University of Helsinki. Social psychological studies 6 .

HUTCHINSON, ELIZABETH (2008). Dimensions of Human Behavior: The Changing Life Course. Virginia Commonwealth University: Sage Publications

JOSEPH, MIRANDA (2014). Debt to society: Accounting for life under capitalism. Minneapolis, MN: University of Minnesota Press.

KAMLER, BARBARA. \& THOMSON, PAT (2008), The Failure of Dissertation Advice Books: Toward Alternative Pedagogies for Doctoral Writing. Educational Researcher, vol. 37, no. 8, pp. 507-514.

KERN, LESLIE, HAWKINS, ROBERTA, AL-HINDI, KAREN F., \& MOSS, PAMELA (2014). A collective biography of joy in academic practice. Social \& Cultural Geography, 15(7), 834-851. http://doi.org/10.1080/14649365.2014.929729 
KLOCKER, NATASHA., \& DROZDZEWSKI, DANIELLE. (2012). Survival and subversion in the neoliberal university, Invited response to AntipodeFoundation.org Symposium on the Participatory Geographies Research Group's 'Communifesto for fuller geographies: Towards mutual security'. Retrieved from http://radicalantipode.files.wordpress.com/2012/10/klocker-anddrozdzewski-response.pdf

KULU, HILL \& MILEWSKI, NADJA. (2007). Family change and migration in the life course: An introduction. Demographic Research, vol. 17, no. 19, 567-590.

LESLIE, SARAH, CIMPIAN, ANDREI, MEYER, MEREDITH \& FREELAND, EDWARD (2015). Expectations of brilliance underlie gender distributions across academic disciplines. Science, 347(6219), 262-265.

LUND, REBECCA. W. B. (2015). Doing the Ideal Academic - Gender, Excellence and Changing Academia. Aalto University. Retrieved from https://aaltodoc.aalto.fi:443/handle/123456789/17846

MACOUN, ALISSA., \& MILLER, DANIELLE (2014). Surviving (thriving) in academia: feminist support networks and women ECRs. Journal of Gender Studies, 23(3), 287-301. http://doi.org/10.1080/09589236.2014.909718

MADDRELL, AVRIL., STRAUSS, KENDRA, THOMAS, NICOLA J., WYSE, STEPHANIE (2016). Mind the gap: gender disparities still to be addressed in UK Higher Education geography. Area - Wiley Online Library.

MÄHLCK, PAULA (2013). Academic women with migrant background in the global knowledge economy: Bodies, hierarchies and resistance. In Women's Studies International Forum, Vol. 36, pp. 65-74. Elsevier.

MAHTANI, MINELLE (2004). Mapping race and gender in the academy: The experiences of women of colour faculty and graduate students in Britain, the US and Canada. Journal of Geography in Higher Education, 28(1), 91-99.

MARTINSSON, LENA, GRIFFIN GABRIELE, AND NYGREN, KATARINA G. (2016). Introduction: challenging the myth of gender equality in Sweden. In: Martinsson, N., Griffin G., and Nygren, K.G. (eds.) 1-22. Challenging the myth of gender equality in Sweden. Bristol: Polity Press.

MILKMAN, KATHERINE. L., AKINOLA, MODUPE, \& CHUGH, DOLLY (2015). What happens before? A field experiment exploring how pay and representation differentially shape bias on the pathway into organizations. Journal of Applied Psychology, 100(6), 1678-1712. http://doi.org/10.1037/ap10000022 
MOSS-RACUSIN, CORINNE. A., DOVIDIO, JOHN. F., BRESCOLL, VICTORIA L., GRAHAM, MARK J., \& HANDELSMAN, JO (2012). Science faculty's subtle gender biases favor male students. Proceedings of the National Academy of Sciences, 109(41), 16474-16479. http://doi.org/10.1073/pnas.1211286109

MOUNTZ, ALLISON, BONDS, ANNE, MANSFIELD, BECKY, LOYD, JENNA, HYNDMAN, JENNIFER, WALTON-ROBERTS, MARGARET, CURRAN, WINIFRED. (2015). For Slow Scholarship: A Feminist Politics of Resistance through Collective Action in the Neoliberal University. ACME: An International E-Journal for Critical Geographies, 14(4), 1235-1259.

MOUNTZ, ALLISON (2016). Women on the edge: Workplace stress at universities in North America. The Canadian Geographer / Le Géographe canadien. 60(2), 205218.

PARIZEAU, KATE, SHILLINGTON, LAURA, HAWKINS, ROBERTA, SULTANA, FARHANA, MOUNTZ, ALISSON, MULLINGS, BEVERLEY \& PEAKE, LINDA (2016) Breaking the silence: A feminist call to action. The Canadian Geographer / Le Géographe canadien. 60(2). 192-204.

PITT, RACHEL, \& MEWBURN, INGER (2016). Academic superheroes? A critical analysis of academic job descriptions. Journal of Higher Education Policy and Management, O(0), 1-14. http://doi.org/10.1080/1360080X.2015.1126896

POWELL, STINA (2016). Gender equality and meritocracy [Doctoral thesis]. Uppsala : Sveriges lantbruksuniv., Acta Universitatis agriculturae Sueciae, 1652-6880 ; ISBN 978-91-576-8536-0

RICE, CURT (2012, May 24). Why women leave academia and why universities should be worried. Retrieved May 20, 2016, from http://www.theguardian.com/higher-education-network/blog/2012/may/24/whywomen-leave-academia

RICHMAN, PHYLLIS. (2013, June 6). Answering Harvard's question about my personal life, 52 years later. The Washington Post. Retrieved from https://www.washingtonpost.com/opinions/answering-harvards-question-aboutmy-personal-life-52-years-later/2013/06/06/89c97e2e-c259-11e2-914fa7aba60512a7 story.html

SACO. (2013). Så kortar vi vägen till svensk arbetsmarknad - Retrieved May 19, 2016, from http://www.saco.se/vara-fragor/rapporter/sa-kortar-vi-vagen-till-svenskarbetsmarknad/?epieditmode=true 
SCHOUGH, KATARINA (2002). Svensk kulturgeografi och feminism : rötter och rörelser $i$ en rumslig disciplin, Karlstad University studies, 1403-8099 ; 2002:3 edn, Karlstad : Univ., Inst. för samhällsvetenskap, Kulturgeografi, Karlstad.

SHAUMAN, KIMBERLEE A. \& XIE, YU (1996). Geographic Mobility of Scientists: Sex Differences and Family Constraints. Demography, 33(4), 455-468.

SIT. (2014). Tänk Om! Sveriges Internationella Talanger, Stockholm, Sweden.

SULF. Sveriges Lärarförbund. (2014) För ett sundare forskningsklimat. Retrieved May 19, 2016, from http://www.sulf.se/Universitetslararen/Arkiv/2014/Nummer-1314/For-ett-sundare-forskningsklimat/

SWAN, ELAINE. (2010). States of white ignorance, and audit masculinity in English higher education. Social Politics: International Studies in Gender, State and Society, 17, 477-506. doi: 10.1093/sp/jxq016

VERD, JOAN M. \& ANDREU, MIGUEL L. (2011). The Rewards of a Qualitative Approach to Life-Course Research. The Example of the Effects of Social Protection Policies on Career Paths. FQS Forum: Qualitative Social Research,[Online],12(3).

WAINWRIGHT, EMMA, BARKER, JOHN, ANSELL, NICOLA, BUCKINGHAM, SUSAN, HEMMING, PETER, \& SMITH, FIONA (2014). Geographers out of place: institutions, (inter) disciplinarity and identity. Area, 46(4), 410-417. http://doi.org/10.1111/area.12126

WILLIAMS, JOAN, PHILLIPS, KATHERINE W., \& HALL, ERIKA V. (2014). Double Jeopardy?: Gender Bias Against Women of Color in Science.

WINKLER, JULIE. A. (2000). Focus Section: Women in Geography in the 21st Century: Faculty Reappointment, Tenure, and Promotion: Barriers for Women. The Professional Geographer, 52(4), 737-750. http://doi.org/10.1080/00330124.2000.9628423

WORLD ECONOMIC FORUM (2015). The global gender gap report 2015. (Inside Report - 10th Anniversary Edition). Switzerland: World Economic Forum. doi:978-92-95044-41-8. 